\title{
PRENATAL YOGA UNTUK MENGURANGI NYERI PUNGGUNG PADA IBU HAMIL TRIMESTER III
}

\author{
Dyah Ayu Wulandari, Euis Ahadiyah, Fitria Hikmatul Ulya \\ STIKes Karya Husada Semarang JIn.Kompol R.Soekanto No.46 Semarang, 0246724581 \\ tata.talitha@gmail.com
}

\begin{abstract}
ABSTRAK
Nyeri punggung merupakan kejadian yang sering terjadi pada ibu hamil dan akan meningkat keluhannya saat ibu memasuki Trimester III. Penyebab nyeri punggung antara lain peningkatan berat badan selama hamil. Salah satu upaya untuk mengurangi nyeri punggung pada ibu hamil dengan prenatal yoga. Prenatal yoga dapat membantu ibu hamil dalam melenturkan persendian karena bertambahnya berat badan selama kehamilan dan dapat digunakan untuk relaksasi pikiran ibu selama kehamilan. Penelitian ini bertujuan untuk megetahui efektivitas prenatal yoga untuk mengurangi nyeri punggung pada ibu hamil Trimester III. Jenis penelitian kuantitatif dengan menggunakan satu kelompok intervensi dengan sampel ibu hamil trimester III sebanyak 18 responden yang diambil secara purposive sampling. Instrument yang digunakan untuk mengukur nyeri punggung adalah Numeric Rating Scale (NRS) dengan analisis bivariat dengan uji Wilcoxon. Hasil penelitian menunjukkan $p$ value 0,000 yang artinya ada pengaruh prenatal yoga terhadap nyeri punggung pada ibu hamil trimester III. Kesimpulan dalam penelitian ini prenatal yoga dapat mengurangi nyeri punggung ibu hamil trimester III.
\end{abstract}

Kata kunci : prenatal yoga; nyeri punggung; ibu hamil trimester III

\section{PRENATAL YOGA TO REDUCE BACK PAIN IN TRIMESTER III PREGNANT MOTHER}

\begin{abstract}
Back pain is a common occurrence in pregnant women and will increase when mothers in third trimester. The causes of back pain include weight gain during pregnancy. One of the efforts to reduce back pain in pregnant women is prenatal yoga. Prenatal yoga can help pregnant women in flexing the joints due to weight gain during pregnancy and can be used to relax the mind of the mother during pregnancy. This study was aimed to determine the effectiveness of prenatal yoga to reduce back pain in third trimester pregnant women. The research quantitative method used one intervention group with a sample of 18 third trimester pregnant women who will be taken by purposive sampling. The instrument used to measure back pain was the Numeric Rating Scale (NRS). Data analysis used Wicoxon test obtained p value 0,000 which means prenatal yoga can reduce back pain in third trimester pregnant women. The conclusion in this study prenatal yoga can be used as an alternative treatment for third trimester pregnant women who experience back pain.
\end{abstract}

Keywords: prenatal yoga; back pain; third trimester pregnant women 


\section{LATAR BELAKANG}

Kehamilan adalah peristiwa yang didahului dengan bertemunya sel telur atau ovum dengan sel sperma. Proses kehamilan akan berlangsung selama kira-kira 10 bulan lunar, atau 9 bulan kalender, atau 40 minggu, atau 280 hari yang dihitung dari hari pertama periode menstruasi terakhir. Kehamilan adalah Pertemuan antara sel telur dengan sel spermatozoa (konsepsi) yang diikuti dengan perubahan fisiologis dan psikologis. Kehamilan berlangsug kurang lebih 200 hari (40 minggu) dan tidak lebih dari 300 hari (43 minggu). Kehamilan 40 minggu disebut dengan kehamilan matur (cukup bulan). Kehamilan 23 dan 35 minggu disebut kehamilan premature. (Brayshaw, 2013). Berdasarkan Kementerian Kesehatan Republik Indonesia (Kemenkes RI) tahun 2016, jumlah ibu hamil di Indonesia mencapai 5.354 .594 orang. Tingkat prevalensi yang tinggi pada nyeri punggung bawah selama kehamilan dilaporkan terjadi di Eropa, Amerika, Australia, China, termasuk wilayah pegunungan daerah pedesaan Taiwan dan Afrika serta di antara perempuan kelas atas di Nigeria. Hasil penelitian yang dilakukan di Amerika Latin menunjukkan adanya peningkatan angka kejadian nyeri punggung bawah yang signifikan selama 14 tahun terakhir dari 3,9\% pada tahun 1992 sampai 10,2\% pada tahun 2006 (Fauziah \& Sutejo, 2012)

Berdasarkan hasil penelitian yang dilakukan Beddoe et al (2009) :" The effects of mindfulness-based yoga during pregnancy on maternal psychological and physical distress" dalam Bonura (2014) menunjukkan efek menguntungkan dari dilakukannya yoga pada wanita hamil yaitu dapat mengurangi stres dan kecemasan.

Penelitian Apriliyani Mafikasari dan Ratih Indah Kartikasari (2015), prevalensi ibu hamil yang mengalami nyeri punggung bawah di berbagai daerah Indonesia mencapai $60-80 \%$. Sementara di Jawa Tengah sendiri, walaupun data epidemiologi mengenai nyeri punggung bawah belum ada, namun diperkirakan angka kejadian nyeri punggung bawah sebesar $40 \%$. Data dari Dinas Kesehatan Kabupaten Kendal, angka kejadian nyeri punggung pada ibu hamil tahun 2017 sebesar 16,593, kejadian pada trimester I sebanyak 3,318 trimester II sebanyak 4,977 dan trimester III sebanyak 8,296 sedangkan pada tahun 2018 sebesar 17,341 , kejadian pada trimester I sebanyak 3,468 trimester II sebanyak 5,202 dan trimester III sebanyak 8,670 di Puskesmas Cepiring Kabupaten Kendal tahun 2017 ibu hamil yang memeriksakan kehamilannya sekitar 870 orang yang merasakan nyeri punggung trimester III sebanyak 435 sedangkan tahun 2018 sebanyak 890 orang yang merasakan nyeri punggung pada trimester III sebanyak 445 .

Ada beberapa keluhan yang muncul pada kehamilan yaitu mual dan muntah, dapat muncul pada bulan ke-1 dan hilang setelah bulan ke-3, mual muntah terjadi saat pagi hari yang disebut dengan morning sickness. Sakit pinggang, sebagian besar dikarenakan perubahan sikap badan selama kehamilan dan titik berat badan pindah kedepan disebabkan perut yang membesar, varises, dipengaruhi oleh faktor keturunan, berdiri lama dan usia, ditambah faktor hormonal (progesterone) dan bendungan dalam panggul. Sakit kepala, biasa di rasakan pada ibu hamil muda yang sulit menyebutkan penyebabnya. Oedema adalah pembengkakan yang sering terjadi pada kaki dan tungkai bawah. Sesak nafas yang disebabkan rahim membesar, mendesak diafragma ke atas. (Lukman \& Ningsih, 2009)

Nyeri punggung bawah adalah ketidaknyamanan yang terjadi dibawah costa dan di atas bagian inferior glueteal. Nyeri punggung bawah adalah gangguan yang umum terjadi, dan ibu hamil mungkin saja memiliki riwayat "sakit punggung" dimasa lalu. Nyeri punggung bawah sangat sering terjadi dalam kehamilan sehingga digambarkan sebagai salah satu gangguan minor dalam kehamilan, gejala nyeri biasanya terjadi antara 4-7 bulan usia kehamilan dan nyeri biasanya terasa di punggung bagian bawah, terkadang menyebar ke bokong dan paha, dan terkadang turun ke kaki sebagai siatika. (Purwaningsih \& Fatmawati, 2010)

Penelitian Lina Fitriani (2018) tentang Efektivitas Senam Hamil Dan Yoga Hamil 
Terhadap Penurunan Nyeri Punggung Pada Ibu Hamil Trimester III didapatkan hasil senam hamil efektif dalam menurunkan nyeri punggung bawah pada ibu hamil Trimester III.

Nyeri tersebut dapat menimbulkan kesulitan berjalan. Nyeri punggung ini dapat bersifat muskulosketal atau dapat berhubungan dengan gangguan panggul seperti infeksi. Komplikasi lain dari nyeri punggung adalah perburukan mobilitas yang dapat menghambat aktifitas seperti mengendarai kendaraan, merawat anak dan mempengaruhi pekerjaan ibu, insomnia yang menyebabkan keletihan dan iritabilitas (Wagiyo\& Putrono, 2016)

Senam prenatal yoga merupakan modifikasi dari senam yoga dasar yang disesuaikan gerakannya dengan kondisi ibu hamil. Yoga adalah suatu olah tubuh, pikiran dan mental yang sangat membantu ibu hamil dalam melenturkan persendian dan menenangkan pikiran terutama pada ibu hamil trimester II dan III. Gerakan dalam prenatal yoga dibuat dengan tempo yang lebih lambat dan menyesuaikan dengan kapasitas ruang gerak ibu hamil (Wagiyo\& Putrono, 2016)

Penelitian ini bertujuan mengetahui prenatal prenatal yoga terhadap nyeri punggung pada ibu hamil Trimester III

\section{METODE}

Penelitian ini merupakan penelitian kuantitatif dengan desain penelitian eksperimen semu (quasy experiment) dan rancangan penelitiannya adalah pre-post test without control group. Sampel dalam penelitian ini adalah 18 ibu hamil dengan kriteria Trimester III (28-36 minggu), yang mengalami nyeri punggung dan tidak mengalami komplikasi dalam kehamilan.Teknik sampling dalam penelitian ini adalah teknik purposive sampling, dimana peneliti memilih responden berdasarkan kriteria yang sudah ditentukan sehingga responden tersebut dapat memberikan data yang dibutuhkan peneliti. Data yang diambil pada penelitian ini adalah nyeri punggung pada ibu hamil Trimester III sebelum intervensi dan sesudah intervensi. Intervensi dilakukan dengan memberikan prenatal yoga 6 kali selama 30 menit dan nyeri punggung diukur menggunakan Numeric Rating Scale (NRS). Uji statistik yang digunakan adalah Uji beda dengan melihat sumber data dalam bentuk skala rasio (numerik), sehingga data diuji normalitas terlebih dahulu menggunakan saphiro wilk. Statistik parametrik yang digunakan adalah uji Wilcoxon karena kedua kelompok data berdistribusi normal.

\section{HASIL}

Analisis univariat pada penelitian ini dengan dengan meliahat nilai mean, minimum, maksimum dan standar deviasi (pada tabel 1) dan analisis bivariat untuk mengetahui pengaruh prenatal yoga terhadap nyeri punggung pada ibu hamil Trimester III (pada tabel 2).

\section{Tabel 1. Pengaruh Prenatal Yoga Terhadap Nyeri Punggung Pada Ibu Hamil Trimester III $(n=18)$}

\begin{tabular}{lccccc}
\hline $\begin{array}{c}\text { Nyeri } \\
\text { punggung }\end{array}$ & Mean & Min & Max & SD & $\begin{array}{c}\boldsymbol{P} \\
\text { value }\end{array}$ \\
\hline Sebelum & 5,11 & 4 & 7 & 0,963 & 0 \\
\hline Sesudah & 3,83 & 3 & 5 & 0,786 & 0,000 \\
\hline
\end{tabular}

Tabel 1 menunjukkan rata-rata nyeri punggung pada ibu hamil trimester III sebelum dilakukan prenatal yoga adalah 5,11 dan sesudah dilakukan prenatal yoga berubah menjadi 3,83 , yang artinya terjadi penurunan nyeri punggung dengan $p$ value $0,000<0,05$ (taraf siginifikansi), yang berarti ada pengaruh prenatal yoga terhadap nyeri punggung pada ibu hamil trimester III.

\section{PEMBAHASAN}

Nyeri punggung yang dialami ibu hamil dikarenakan terjadi peningkatan berat badan dan fisiologi tulang belakang. Adanya kelengkungan tulang belakang ibu hamil yang meningkat kearah akhir kehamilan dan perubahan postur tubuh (Yoo, Shin \& Song, 2015) Adanya ketidakseimbangan antara otot agonis dan anatagonis, yaitu $M$ erector spine dan kelompok neksor lumbalis. Keadaan atau posisi yang salah tersebut jika berlangsung 
lama akan menimbulkan ketegangan pada ligament dan otot yang menyebabkan kelelahan pada M. abdomanalis uterus yang membesar akan memperbesar derajat lordosis sehingga sering menyebabkan sakit pinggang (Siswosudarmo, 2012).

Nyeri punggung dapat menimbulkan kesulitan berjalan dan dapat bersifat muskulosketal atau dapat berhubungan dengan gangguan panggul seperti infeksi. Komplikasi lain dari nyeri punggung adalah menurunkan mobilitas yang dapat menghambat aktifitas seperti mengendarai kendaraan, merawat anak dan mempengaruhi pekerjaan ibu, insomnia yang menyebabkan keletihan dan iritabilitas. Penanganan dalam asuhan kebidanan yaitu memberikan pendidikan individu dapat mengurangi gejala dengan memberdayakan ibu untuk memahami kondisi mereka, memberikan perawatan punggung, dianjurkan untuk mempertahankan tingkat aktifitas yang nyaman bagi mereka. Upaya untuk menangani nyeri punggung ada farmakologis dan non farmakologis, terapi farmakologis bisa diberikan dengan agen antiinflamasi non-steroid, analgesic, relaksan otot. (Wagiyo\& Putrono, 2016)

Penelitian yang dilakukan oleh Octavia AM (2018) bahwa dengan melakukan senam yoga dengan teratur dapat mempengaruhi nyeri punggung selama kehamilan. Nyeri punggung pada kehamilan merupakan nyeri punggung yang terjadi pada area lumbosakral. Nyeri punggung biasanya akan meningkat intensitasnya seiring pertambahan usia kehamilan karena nyeri ini merupakan akibat pergeseran pusat gravitasi dan postur tubuhnya.

Penelitian yang dilakukan oleh Devi M (2014) tentang pengaruh yoga antenatal terhadap pengurangan keluhan ibu hamil trimester III dengan perlakuan yoga antenatal sebanyak 4 kali pada ibu hamil trimester III yang tidak mengalami komplikasi, tidak ada riwayat persalinan premature dan pertumbuhan perkembangan janin sesuai dengan usia kehamilan. Hasil penelitian menunjukkan ratarata keluhan ibu hamil pada pengukuran sebelum dilakukan yoga antenatal adalah 12,78 dan sesudah dilakukan 12,19 dengan $p$ value
0,005 yang artinya ada perbedaan yang signifikan antara keluhan ibu hamil sebelum dan setelah dilakukan yoga antenatal.

Hasil penelitian menunjukkan nilai tengah nyeri punggung pada ibu hamil trimester III sesudah dilakukan prenatal yoga berskala 4 kategori sedang, analisa peneliti responden merasa antusias ketika latihan prenatal yoga bersama walaupun di minggu pertama banyak yang merasa pegal-pegal tetapi karena mereka sudah mendapatkan informasi jika prenatal yoga adalah lebih menguntungkan ibu dalam ragkaian persiapan tubuhnya menghadapi persalinan dan dapat mengurangi keluhan seperti nyeri punggung maka mereka menjadi bersemangat. (Latief, 2016)

Dr. Vivek Narendran dari Ciccinnati Children's Hospitality Medical Center di Ohio Amerika Serikat mengatakan latihan yoga dapat membantu memperlancar aliran darah ke plasenta, menurunkan transfer hormon stres ibu ke tubuh janin, menurunkan pelepasan hormon yang memicu terjadinya kelahiran sehingga memperkecil kemungkinan kelahiran prematur. Prenatal yoga memiliki lima cara yaitu latihan fisik yoga, pernafasan (pranayama), position (mudra), meditasi, dan deep relaksasi yang dapat digunakan untuk mendapatkan manfaat selama kehamilan sehingga dapat membantu kelancaran dalam kehamilan dan kelahiran secara alami dan membantu memastikan bayi yang sehat. Unsur pada yoga yang dikatakan dapat membantu menurunkan kecemasan adalah pada bagian relaksasi dan meditasi. Yoga selama kehamilan dapat membantu wanita fokus pada proses persalinan, bersiap untuk mentolerir nyeri,serta mengubah stres dan kecemasan menjadi energy. (Wagiyo \& Putrono, 2016)

Berdasarkan penelitian yang dilakukan oleh Fauziah L (2016) bahwa ibu primigravida yang melakukan kelas ibu hamil menunjukkan penurunan kecemasan terkait proses persalinan, menambah keyakinan dan kemampuan diri terkait persalinan, serta mengurangi keluhan fisik. Hal ini dikarenakan yoga dapat membantu posisi ibu hamil lebih tepat, dan nyaman karena yoga menciptakan ruang pada torso, di dalam yoga tidak 
melakukan postur yang terlalu banyak memberikan tekanan atau tarikan pada sendi yang berpotensi cedera (Aprilia, 2014). Latihan yoga yang dilakukan diantaranya mencakup postur yoga (asanas), olah pernafasan (pranayama) dan pendinginan (relaksasi), pikiran (mind) dan nutrisi.

Mekanisme prenatal yoga yaitu prenatal yoga dapat menciptakan "ruang" bagi ibu dan janin untuk tetap dapat bernafas dengan nyaman, melatih otot dasar panggul agar lebih elastis dan kuat, serta melakukan postur-postur restoratif dan relaksasi sehingga berguna dalam menghadapi persalinan (Mediarti, 2014).

\section{KESIMPULAN DAN SARAN}

Simpulan penelitian ini adalah prenatal yoga dapat mengurangi keluhan nyeri punggung pada ibu hamil trimester III. Saran untuk Ibu hamil sebaiknya melakukan salah satu treatment prenatal yoga untuk mengurangi keluhan nyeri punggung dan persiapan dalam menghadapi persalinan minimal 1 minggu 1 kali.

\section{REFERENSI}

Bingan Eline CS. (2019). Pengaruh Prenatal Gentle Yoga dalam Menurunkan Tingkat Kecemasan pada Ibu Hamil trimester III. Jurnal Kesehatan, Volume 10, Nomor 3, November 2019

Bonura, K. B. (2014). Yoga Mind While Expecting : The Psychological Benefits of Prenatal Yoga Practice. International Journal of Childbirth Education.

Brayshaw. (2013). Senam Hamil \&Nifas Pedoman Praktik Bidan. Jakarta:EGC.

Devi, M, dkk. (2014). Pengaruh Yoga Antenatal Terhadap Pengurangan Keluhan Ibu Hmail Trimester III. Jurnal kedoktran dan Kesehatan Volume 1, No 1, Oktober 2014
Lestari, F. (2016). Efetivitas Latihan Yoga Prenatal dalam menurunkan Kecemasan pada Ibu Primigravida. Bandung: Universitas Padjadjaran

Latief. (2016). Fisioterapi Obstetri-Ginekologi. Jakarta: Buku Kedokteran EGC

Fitriani, Lina. (2018). Efektivitas Senam Hamil Dan Yoga Hamil Terhadap Penurunan Nyeri Punggung Pada Ibu Hamil Trimester III Di Puskesmas Pekkabata. Jurnal Kesehatan Masyarakat, Vol 4, No 2,Nov 2018 (72-80).

Lukman \& Ningsih. (2009). Asuhan Keperawatan Pada Klien Dengan Gangguan Sistem Muskulosketal. Jakarta: Salemba Medika

Mafikasari \& Kartikasari. (2015). Posisi Tidur Dengan Kejadian Back Pain (Nyeri Punggung) Pada Ibu Hamil Trimester III. Jurnal Kebidanan, Vol. 07, No. 02.

Mitayani. (2009). Asuhan Keperawatan Maternitas. Jakarta: EGC

Octavia AM. (2018). Pengaruh Senam Yoga Terhadap Nyeri Punggung Pada Ibu Hamil Trimester III. STIKES Insan Cendekia Medika Jombang.

Purwaningsih \& Fatmawati. (2010. Asuhan Keperawatan Maternitas. Yogyakarta: Nuha Medika

Siswosudarmo \& Emilia. (2012). Obsterti Fisiologi. Yogyakarta: Pustaka Cendekia.

Wagiyo\& Putrono. (2016). Asuhan Keperawatan Antenatal, Intranatal \& bayi baru lahir fisiologis dan patologis. Yogyakata :CV.Andi

Yoo, Shin \& Song. (2015). Changes In The Spinal Curvature, Degree of pain, Balance Ability, And Gait Ability According To Pregnancy Period In Pregnant And Nonpregnant Women. J. Phys. Ther. Sci, Vol.27, No.01 